Para enlazar con este artículo / To link to this article:

http://dx.doi.org/10.6035/MonTI.2019.ne4.7

Para citar este artículo / To cite this article:

MONTI, Silvia. (2019) "What's cooking in multicultural films? Food, language and identity in British and American audiovisual products and their Italian dubbed version." In: Pérez L. de Heredia, María \& Irene Higes Andino (eds.) 2019. Multilingüismo y representación de las identidades en textos audiovisuales / Multilingualism and representation of identities in audiovisual texts. MonTI Special Issue 4, pp. 199-228.

\title{
WHAT'S COOKING IN MULTICULTURAL FILMS? FOOD, LANGUAGE AND IDENTITY IN BRITISH AND AMERICAN AUDIOVISUAL PRODUCTS AND THEIR ITALIAN DUBBED VERSION
}

\author{
Silvia Monti \\ silvia@netcomp.it \\ Università di Pavia
}

\begin{abstract}
In a world in which multiculturalism and multilingualism pervade every layer of society, much attention has been recently focused on exploring the symbolic relevance of socio-cultural traditions in multiethnic contexts of interaction. In particular, contemporary British and American films often investigate the importance of ethnic food as a key entry to cultural and linguistic memory in immigrant communities in Europe and the USA. Starting from these observations, this paper sets out to investigate the socio-cultural and linguistic functions food naming serves as an identity/ethnicity tool in both the original and the Italian dubbed version of such intercultural films as Bend it Like Beckham, My Big Fat Greek Wedding, Ae Fond Kiss, The Mistress of Spices, My Life In Ruins, Eat Pray Love, The Hundred-Foot Journey, My Big Fat Greek Wedding 2, where the immigrant characters express their hybrid identity through the recurrent use of intra-sentential code-switching (Myers-Scotton 1993) from they-code to we-code (Gumperz 1982) when quoting the original names of their traditional dishes, thus symbolically and linguistically representing the transcultural and translanguaging space (Wei 2011) they live in.
\end{abstract}

\section{Riassunto}

In un mondo in cui multiculturalismo e multilinguismo pervadono ogni ambito della società, una sempre crescente attenzione viene rivolta all'importanza delle tradizioni socioculturali in contesti interazionali multietnici. In particolare, molti film britannici e americani contemporanei focalizzano la propria attenzione sul ruolo simbolico che il cibo ricopre, a livello tanto culturale quanto linguistico, nelle numerose comunità di 
immigrati presenti sul suolo britannico e americano. A partire da queste osservazioni, l'articolo si propone di analizzare le funzioni socioculturali, identitarie e linguistiche che i riferimenti ai nomi delle specialità culinarie proprie di tali comunità rivestono nella versione originale e nella versione italiana doppiata di alcuni film interculturali quali Bend it Like Beckham, My Big Fat Greek Wedding, Ae Fond Kiss, The Mistress of Spices, My Life In Ruins, Eat Pray Love, The Hundred-Foot Journey, My Big Fat Greek Wedding 2, dove gli immigrati protagonisti delle vicende danno voce alla propria identità ibrida attraverso un uso ricorrente del cosiddetto intra-sentential code-switching (Myers-Scotton 1993) passando da they-code a we-code (Gumperz 1982) nel citare i nomi originali dei loro cibi tradizionali, ed esprimendo così, a livello tanto linguistico quanto simbolico, lo spazio transculturale e translinguistico (Wei 2011) nel quale vivono.

Keywords: Audiovisual translation. Multilingualism. Code-switching. Ethno-cultural specifics. Transcultural transmission.

Parole chiave: Traduzione audiovisiva. Multilinguismo. Code-switching. Riferimenti socioculturali. Trasmissione transculturale. 


\section{Multiculturalism, multilingualism and food on the screen}

In a world in which multiculturalism and multilingualism pervade almost every layer of society, as cross-cultural encounters constantly intensify through migration, tourism and globalization, much attention has been recently focused on exploring social and cultural identities in multiethnic and multilingual contexts of interaction (cf. Carter 2004; Bathia, Ritchie 2012; Edwards 2012; Kelly-Holmes \& Milani 2013; Siemund, Gogolin, Schulz \& Davydova 2013; Anchimbe 2014). These are increasingly represented in multicultural audiovisual products that often focus their attention on the symbolic relevance of socio-cultural and culinary traditions in immigrant communities in Europe and the USA, considering them as crucial entries to the immigrant characters' cultural and linguistic memory. In particular, many contemporary British and American films often investigate the importance of ethnic food as a main vehicle of self-representation (cf. Bower 2004) in European and American multiethnic societies, dealing with the themes of cultural conflict, alienation and assimilation in considering ethnic eating habits as tropes for the clash between European/American and non-European/American worlds as well as tools to negotiate "otherness" and to create a common ground in which "otherness" can be embraced. This supports the on-screen construction of convincing imitations of real-life multilingual interactions, within which code-switching, i.e. "the selection by bilinguals or multilinguals of forms from an embedded variety (or varieties) in utterances of a matrix variety during the same conversation" (Myers-Scotton 1993: 3) proves to be a key linguistic procedure; this is particularly the case when it is used to mention the original names of the immigrant characters' food specialties, thus also showing how socio-historical context is strictly tied to the use of language in social interaction (Bucholtz \& Hall 2005).

Starting from these observations, this paper sets out to investigate the functions food naming serves as an identity/ethnicity tool in both the original and the Italian dubbed version of such intercultural films as Bend it Like 
Beckham $^{1}$ (Gurinder Chadha 2002), My Big Fat Greek Wedding² (Joel Zwick 2002), Ae Fond Kiss ${ }^{3}$ (Ken Loach 2004), The Mistress of Spices ${ }^{4}$ (Paul Mayeda Berges 2008), My Life In Ruins ${ }^{5}$ (Donald Petrie 2009), Eat Pray Love ${ }^{6}$ (Ryan Murphy 2010), The Hundred-Foot Journey ${ }^{7}$ (Lasse Hallström 2014), My Big Fat Greek Wedding $2^{8}$ (Kirk Jones 2016). These significantly illustrate how the intricate socio-cultural and linguistic dynamics to be recognized within

1. Bend it Like Beckham tells the story of eighteen-year-old British-Asian Jess Bhamra, who has grown up in the western suburbs of London in a Sikh family of tradition-bound Asian immigrants but, despite her parents' grounded roots and the conventional plans they have for her future, joins the local women's soccer team and falls in love with her white coach.

2. My Big Fat Greek Wedding centers on Toula Portokalos, a middle class Greek-American woman who falls in love with a non-Greek upper middle class man and struggles to get her family to accept him while she herself comes to terms with her heritage and cultural identity.

3. Ae Fond Kiss revolves around the relationship between Casim Khan, a second-generation Pakistani working as a DJ in Glasgow, and Roisin, an Irish Catholic schoolteacher, highlighting the clash of cultures and personalities that arises when their relationship is discovered.

4. In The Mistress of Spices, Tilo, grown up in India in a sort of traditional cult of spices, becomes a Mistress of Spices and is sent to the Spice Bazaar in San Francisco, with the mission of following three basic rules: use the spices to help her clients accomplish their desires but never hers; never leave the store; and never be touched in the skin. When she meets the American architect Doug, she falls in love with him, breaking the rules and being punished by the spices with a series of consequences for both herself, her lover and her customers.

5. In My Life in Ruins, Georgia, a college professor of Classical Greek Studies, takes a job as a tour guide, guiding a group of stereotypical tourists around Greece. Along the way, she begins to see the world through new eyes, also realizing that true love may be closer than she thinks if she could just recapture her kefi (mojo).

6. Liz Gilbert, the main protagonist of Eat Pray Love, had everything a woman is supposed to dream of having - a husband, a house, a successful career - yet she found herself lost and searching for what she really wanted in life. Newly divorced and at a crossroads, Gilbert steps out of her comfort zone, embarking on a journey around the world that becomes a quest for self-discovery. In her travels, she discovers the true pleasure of nourishment by eating in Italy, the power of prayer in India, and, finally and unexpectedly, the inner peace and balance of true love in Bali.

7. The Hundred-Foot Journey tells the story of the Kadam family who move to a small town in France from India after a traumatic event, to start a new life and open their restaurant Maison Mumbai; in the process, they are confronted by Madame Mallory, owner of a Michelin-star rated French restaurant Le Saule Pleureur (literally "the weeping willow") at just one-hundred-foot distance across the street.

8. My Big Fat Greek Wedding 2 portrays the Portokalos family after a few years, with Toula still working in her parents' Greek restaurant, her daughter Paris growing up and getting ready to graduate high school, Toula and Ian experiencing marital issues and Toula's parents finding out they were never officially married, all this with the family's devotion to Greek socio-cultural traditions always to the fore. 
multiethnic realities are often exemplified by foodways that play a key role in the characters' daily life.

What is interesting to observe in these films is that it is essentially through language that food is presented as it is "mentioned", "named", "quoted", "cited" rather than actually cooked. Indeed, the characters, and in particular the immigrant characters, linguistically enact their hybrid identity within their discourse practices through the recurrent use of intra-sentential code-switching (Myers-Scotton 1993) from their they-code (Gumperz 1982; Auer 2005, 2007), i.e. English, into their we-code (Gumperz 1982; Auer 2005, 2007) when quoting the original names of the recipes that are a basic part of their background heritage and therefore function as powerful metaphors for emotional expressivity and experience.

In establishing a specific socio-linguistic and pragmatic framing within which the presence of intra-sentential code-switching related to food naming seems to operate in our corpus of films, the scripts will be analyzed:

- focusing attention on the scenes where the characters' lives are "seasoned" with images of ethnic food as one of the most typical ways of defining and distinguishing their self;

- pointing out the socio-cultural meanings related to food naming that are encoded in both the original and the Italian dubbed versions, illustrating how the reference to the different ethnic foodways represents the "translanguaging space" (Wei 2011: 1222) the immigrant characters live in;

- observing whether, in the Italian dubbed versions of the films, the original food names are either maintained in the spoken exchanges or translated through dubbing, thus losing their figurative function as markers of cultural differentiation.

\section{The linguistic power of ethnic food in audiovisual translation}

The comparative nature of our study, taking into consideration the occurrences of the original names of ethnic food in both the original and the Italian dubbed version of the films under investigation, is basically due to the fact that issues of multilingualism and language variation on the screen are inherently tied to the concept of audiovisual translation, intended as a transcoding process focused not merely on language transfer but also, and primarily, on cross-cultural transfer (Snell-Hornby 1995). With particular regard to multilingual films, we could say that any form of audiovisual translation plays a unique role in developing and communicating transnational linguistic identities as well as 
transcultural stereotypes, all the more so when ethnocultural specifics are at stake (cf. Newmark 1988; Pedersen 2005; Díaz Cintas \& Remael 2007; Chiaro 2009; Ranzato 2016).

From this perspective, what immediately emerges from the contrastive analysis of the original version and the Italian dubbed version of the films included in our corpus is that all occurrences of culinary references, made by means of intra-sentential code-switching, are left unaltered in Italian, following the translation, or non-translation, strategy that has been variously defined as borrowing (cf. Vinay and Darbelnet 1958/2002; Ivir 1987), transference (cf. Newmark 1988), retention (cf. Pedersen 2005; Gottlieb 2009), direct transfer (cf. Leppihalme 2011), loan (Díaz Cintas \& Remael 2007; Chaume 2004). Such overall procedure, adopted within the Italian film industry in particular in the last two decades, apparently goes against the Italian filmmakers' traditional tendency to adhere to norms of monolingualism (Bleichenbacher 2008) involving local standardization (Pavesi 2009, 2005), naturalization and explicitation (Ulrych 2000) and leading to the elimination of code-switching through dubbing. Indeed, it faithfully retains the cultural coloring of the we-code terms and fulfills the crucial role food plays as a symbolic actor in defining the characters' ethnocultural difference, thus also confirming the assumption that "Dubbing should create the perfect illusion of allowing the audience to experience the production in their own language without diminishing any of the characteristics of the original language, culture and national background" (Dries 1995: 9).

\section{What's cooking in multicultural films?}

The first crucial aspect the films in our corpus clearly highlight is that ethnic food is always placed in the foreground in the immigrants' life as one of the last bastions of socio-cultural traditions that should be preserved across generations to validate in-group identity models. Indeed, the greatest connection between the first-, second- and third-generation immigrants represented on the screen seems to be given by the food they prepare faithfully respecting their homeland culinary practices while living a life at a point of cultural adjustment.

\subsection{Food and identity}

The role ethnic eating habits play as identity icons in the daily life of the members of immigrant communities can be observed in most of the films under study. For instance, in Bend It Like Beckham, featuring a family of Punjabi Sikhs in London, Indian food is often evoked in the course of family conversations 
both as a powerful marker of ethnic belonging and as a symbol of the family's well-being (see examples 1-4).

Example 1. Bend It Like Beckham (01:06:56)

\begin{tabular}{|c|c|c|}
\hline $\begin{array}{l}\text { MRS. } \\
\text { BHAMRA TO } \\
\text { PINKY }\end{array}$ & $\begin{array}{l}\text { Chicken, lamb... and paneer } \\
\text { tikka. }{ }^{9} \text { We'll show them, we're not } \\
\text { poor people! }\end{array}$ & $\begin{array}{l}\text { Pollo, agnello... e anche paneer } \\
\text { tikka. Glielo faremo vedere. Non } \\
\text { siamo mica poveri, no? }\end{array}$ \\
\hline
\end{tabular}

Example 2. Bend It Like Beckham (00:03.17)

\begin{tabular}{|c|c|c|}
\hline $\begin{array}{l}\text { MRS. } \\
\text { BHAMRA }\end{array}$ & $\begin{array}{l}\text { Ah, my mother chose all my } \\
\text { twenty-one dowry suits herself. I } \\
\text { never once complained. You girls } \\
\text { are too spoilt. Now don't forget } \\
\text { my dhania, }{ }^{10} \text { four bunches for } \\
\text { a pound and more carrots, I'm } \\
\text { making achar. }{ }^{11}\end{array}$ & $\begin{array}{l}\text { Mia madre scelse lei tutti i } \\
\text { ventuno vestiti del mio corredo e } \\
\text { non mi sono mai lamentata. Voi } \\
\text { due siete troppo viziate. E non } \\
\text { vi scordate il mio dhania, quattro } \\
\text { mazzetti per una sterlina, e un po' } \\
\text { di carote, devo fare achar. }\end{array}$ \\
\hline
\end{tabular}

Example 3. Bend It Like Beckham (01:00:33)

\begin{tabular}{|l|l|l|}
\hline JESS & Bring me back some langar. ${ }^{12}$ & Portatemi un po' di langar. \\
\hline
\end{tabular}

Example 4. Bend It Like Beckham (00:05:32)

\begin{tabular}{|l|l|l|}
\hline PINKY & $\begin{array}{l}\text { Yes, massiji. Mum's making the } \\
\text { samosas. }\end{array}$ & $\begin{array}{l}\text { Sì, ma certo. Mamma prepara le } \\
\text { samosa. }\end{array}$ \\
\hline
\end{tabular}

As far as the rendering of the Punjabi food names in the previous excerpts is concerned, we can notice that they have been left unaltered in both versions except for the term samosas, adapted to the Italian syntactic rules of plural formation as referring to a type of food now well-known and consumed also in Italy.

In this film, Mrs. Bhamra, the family mother, is the character who most recurrently names typical Indian dishes and is constantly portrayed as a matriarchal figure, symbolically dedicating herself to the family's emotional needs also through the food she prepares. This leads us to observe that, in most

9. Bits of Indian cheese.

10. Coriander leaves.

11. A variety of pickled condiments.

12. The free vegetarian meal served after a Sikh service.

13. Small fried turnover of Indian origin filled with seasoned vegetables. 
multiethnic films centered around the building block of the family, culinary terms are often mentioned when clashes in values and identities are negotiated within mother-daughter conflicts. Indeed, the presence and preparation of food on the screen are primarily concerned with the role first-generation immigrant women play in the familial and social structure as conveyors of culinary traditions from one generation to another. Besieged by a way of life that is not their own, grandmothers and mothers are apprehensive of losing their children to forces they cannot control and thus attempt to bring them up according to their home traditions, represented, from a material point of view, by their traditional recipes. By passing the family recipes on to the next generation they are able to preserve elements of their indigenous culture that would otherwise be lost in the Western world they now live in, but the fulfillment of their ambitions in this sense is often complicated by their daughters' attitudes; indeed, second-generation immigrant women don't seem to be particularly interested in learning to cook their homeland specialties, as they are more concentrated on their Western life and rarely demonstrate such traditional forms of "female competence" as preparing food like their mothers.

In particular, in Bend It Like Beckham, Mrs. Bhamra often reproaches her daughter Jess for bending their home socio-cultural paradigms, thinking about her career in football instead of learning how to cook Indian food as all good and dutiful Indian girls do. As a matter of fact, Mrs. Bhamra places food, cooking and education at the top of the list of her priorities: for her, any "good Indian girl" is automatically a wife to be to a "good Indian man" who knows how to cook a perfect full-course North Indian meal; this is proved by the fact that, in many scenes, she tries to make her British-based daughter imbibe as much as possible of her cultural-culinary values, linguistically symbolized by the Punjabi names of some traditional Indian dishes (see example 5).

Example 5. Bend It Like Beckham (00:21:23)

\begin{tabular}{|l|l|l|}
\hline MRS. & $\begin{array}{l}\text { What family will want a daughter- } \\
\text { in-law who can run around } \\
\text { BHAMRA }\end{array}$ & $\begin{array}{l}\text { Quale famiglia vorrebbe una nuora } \\
\text { che corre tutto il giorno appresso } \\
\text { a un pallone ma che non è capace } \\
\text { make round chapattis? }{ }^{14} \text { Now } \\
\text { exams are over, I want you to } \\
\text { learn full Punjabi dinner, meat } \\
\text { and vegetarianito gli esami, imparess a che } \\
\text { cucinare tutto un pranzo Punjabi, } \\
\text { sia carne che verdura! }\end{array}$ \\
\hline
\end{tabular}

14. Indian flatbread, made of wheat flour, water, and salt. 
In this case, as in the previously analyzed case regarding the Italian rendering of the term samosas, the Punjabi term chapattis is adapted to the Italian syntactic rules of plural formation as an instance of lexical borrowing.

In another scene, Mrs. Bhamra tells Jess, with a scornful tone, that when she was her age she was already married and she knew well how to cook Pakistani food such as dhal,$^{15}$ whereas Jess is obviously far from this Indian "stereotype" (see example 6).

Example 6. Bend It Like Beckham (00:20:44)

\begin{tabular}{|l|l|l|}
\hline $\begin{array}{l}\text { MRS. } \\
\text { BHAMRA }\end{array}$ & $\begin{array}{l}\text { I was married at your age and you } \\
\text { don't even want to learn to cook } \\
\text { dhal! }\end{array}$ & $\begin{array}{l}\text { Io ero già sposata alla tua età e tu } \\
\text { non vuoi imparare a cucinare il } \\
\text { dhal! }\end{array}$ \\
\hline
\end{tabular}

Though Jess learns to make "lovely aloo gobi"16 to please her mother (see example 7), she considers playing football more important than cooking Indian food (see example 8).

Example 7. Bend It Like Beckham (00:29:18)

\begin{tabular}{|l|l|l|}
\hline MRS. & $\begin{array}{l}\text { Hey, leave her alone. I never put } \\
\text { make-up until after I was married. } \\
\text { Bessie's a good girl now. She helped } \\
\text { me wash all the net curtains and } \\
\text { she made lovely aloo gobi last } \\
\text { week, eh? }\end{array}$ & $\begin{array}{l}\text { Lascia stare tua sorella. Io non mi } \\
\text { sono mai truccata fino a che mi } \\
\text { sono sposata. Jessie è diventata } \\
\text { brava. Mi ha aiutata a lavare } \\
\text { tutte le tendine. E ha cucinato } \\
\text { un buonissimo aloo gobi l'altra } \\
\text { settimana, eh? }\end{array}$ \\
\hline
\end{tabular}

Example 8. Bend It Like Beckham (00:22:28)

\begin{tabular}{|l|l|l|}
\hline JESS & $\begin{array}{l}\text { Anyone can cook aloo gobi, but who can } \\
\text { bend a ball like Beckham? }\end{array}$ & $\begin{array}{l}\text { Tutte possono cucinare aloo } \\
\text { gobi, ma chi tira in porta come } \\
\text { Beckham? }\end{array}$ \\
\hline
\end{tabular}

The role food plays as a key family-identity tool is to be recognized also in My Big Fat Greek Wedding and My Big Fat Greek Wedding 2, where the Portokalos family, running a Greek restaurant in Chicago, is always humorously depicted as a food-obsessed clan. Indeed, they make their Greek heritage central to their lifestyle constantly cooking Greek dishes and evoking them in their

15. Dried beans.

16. Dry Indian and Pakistani cuisine dish made with aloo, potatoes, and gob(h)i, cauliflower, with Indian spices. 
conversations, as can be seen, in My Big Fat Greek Wedding, when all the family members meet to celebrate Easter and Toula's father proudly enters the scene offering his guests magiritsa, ${ }^{17}$ a Greek soup, which is rendered in this case even more special having been cooked by Uncle Taki (see example 9).

Example 9. My Big Fat Greek Wedding (00:51:08)

\begin{tabular}{|l|l|l|}
\hline TOULA'S & Taki magiritsa! & Taki magiritsa! \\
FATHER & & \\
\hline
\end{tabular}

Another typical tradition related to food that typifies the Portokaloses is that of preparing pastitsio ${ }^{18}$ for the priest of the community, as Toula says when talking to her sister Athena (see example 10).

Example 10. My Big Fat Greek Wedding (00:11:35)

\begin{tabular}{|l|l|l|}
\hline TOULA & $\begin{array}{l}\text { And the pastitsio for the papa, you } \\
\text { told me Athena! Go! }\end{array}$ & $\begin{array}{l}\text { E il pastitsio per il prete, me l'hai } \\
\text { detto Athena! Vai! }\end{array}$ \\
\hline
\end{tabular}

In this film, the distinctiveness of Greek culinary traditions is significantly to be observed on the morning of Toula's wedding with the American Ian Miller (see example 11), when she is surrounded by her female family members, getting ready for the day, and her brother Nicky cries.

Example 11. My Big Fat Greek Wedding (01:13:13)

\begin{tabular}{|l|l|l|}
\hline NICKY & Hello ladies... fresh baklava! ${ }^{19}$ & Buongiorno signore... baklava fresca! \\
\hline
\end{tabular}

Here we notice Toula holding a sweet diamond of baklava in her hand: this means that even though she is going to marry an American guy, and therefore she is going to become American, her "Greek-flavored soul" is still to be, and will always be, "tasted" in the food she eats.

Also in My Big Fat Greek Wedding 2, Greek food is recurrently incorporated into the image as a proper identity symbol. For instance, Toula's great-grandmother, who has never really integrated in the Western world and rarely speaks throughout the whole film, is often portrayed in the act of offering spanakopita; ${ }^{20}$

17. A traditional Easter soup made with lamb offal and thickened with avgolemono. Endives and dill can be added.

18. A baked pasta dish with a filling of ground, spiced minced meat and a béchamel sauce topping.

19. A dessert made of thin pastry, nuts and honey.

20. A pie with spinach, feta cheese, onion, eggs and seasonings. 
this can be seen when, during a party at the American high-school attended by her great-granddaughter Paris, she introduces herself uttering nothing else but the word "Spanakopita!" while giving out slices of this typical Greek pie, in order both to honor her Greek heritage and to impose it within an all-American context (see example 12).

Example 12. My Big Fat Greek Wedding 2 (00:13:39)

\begin{tabular}{|l|l|l|}
\hline MANA-YIAIA & Spanakopita! & Spanakopita! \\
\hline
\end{tabular}

Furthermore, Greek food functions as the perfect comfort food in emotionally difficult situations, as can be observed when Toula tries to console her sad father offering him some baklava (see example 13).

Example 13. My Big Fat Greek Wedding 2 (00:50:23)

\begin{tabular}{|l|l|l|}
\hline TOULA & $\begin{array}{l}\text { Oh dad... I've just made } \\
\text { baklava, you wanna a piece? }\end{array}$ & $\begin{array}{l}\text { Oh papà... ho fatto il baklava, ne vuoi } \\
\text { un pezzo? }\end{array}$ \\
\hline $\begin{array}{l}\text { TOULA'S } \\
\text { FATHER }\end{array}$ & No. & No. \\
\hline TOULA & Chocolate baklava. & Baklava al cioccolato. \\
\hline
\end{tabular}

Greek food waves as an identity flag also in My Life In Ruins, featuring a GreekAmerican tour guide leading a group of European and American tourists in Greece: here Greek food is often placed on center stage as one of the main "tasty" symbols of Greece that foreigners should know, as we can see whenever tourists are offered such mouth-watering specialties of Greek cuisine as warm loukoumades $^{21}$ (see example 14).

Example 14. My Life in Ruins (00:10:09)

\begin{tabular}{|l|l|l|}
\hline NICO & $\begin{array}{l}\text { Hello, beautiful people. I } \\
\text { am Nico. For you, warm } \\
\text { loukoumades. }\end{array}$ & $\begin{array}{l}\text { Salve, bellissima gente. Io sono Nico. } \\
\text { Eccovi delle loukoumades calde. }\end{array}$ \\
\hline
\end{tabular}

In The Hundred-Foot Journey cookery definitely goes beyond mere nourishment, fostering a strong sense of group identity. Indeed, the members of the Kadam family constantly negotiate issues of identity, power and relationships by preparing and offering food imbued with their ethnicity, as Papa, the family father, considers Indian food an important cultural capital, to be strenuously defended

21. Donuts. 
against what he sees as the "otherness" represented by French cuisine. This is underlined at the very beginning of the film when, upon the family arrival in Europe, Hassan, one of the sons, is asked by a customs agent if he has any qualifications as a cook, replies that he has no proof on paper but only on grease-proof paper and offers the customs agent a piece of samosa, considering it as his own identity card (see example 15).

Example 15. The Hundred-Foot Journey (00:03:11)

\begin{tabular}{|l|l|l|}
\hline $\begin{array}{l}\text { CUSTOMS } \\
\text { AGENT }\end{array}$ & You have qualifications? & Ha delle qualifiche? \\
\hline HASSAN & Yes, my mother taught me. & Sì, ho imparato da mia madre. \\
\hline $\begin{array}{l}\text { POLICE } \\
\text { AGENT }\end{array}$ & But no proof on paper? & Ma nessuna carta che lo testimonia. \\
\hline HASSAN & $\begin{array}{l}\text { Only grease-proof paper. } \\
\text { Samosa? }\end{array}$ & No, solo carta da forno. Samosa? \\
\hline $\begin{array}{l}\text { POLICE } \\
\text { AGENT }\end{array}$ & No, thank you. & No, grazie. \\
\hline
\end{tabular}

The fact that Hassan says that he learnt to cook from his mother also leads us to observe that food, especially in multiethnic and immigrant communities, is often associated with memories: the act of cooking brings memories back to life and connects Hassan and his relatives both to the members of their family who still live on the other side of the world and to the spirits of those who are no longer with them but live on in every ingredient. This can be seen when Mr. Kadam stands by the door of his restaurant on the opening day and tries to drag people in as they're passing by mentioning chicken tikka, a delicious Indian specialty that he considers as a sort of visiting card of the Maison Mumbai and that, according to him, the inhabitants of the French village should therefore absolutely try (see example 16).

Example 16. The Hundred-Foot Journey (00:39:19)

\begin{tabular}{|l|l|l|}
\hline MR. & $\begin{array}{l}\text { This is a new restaurant, we } \\
\text { KADened today. It's an Indian } \\
\text { restaurant. Great food. Chicken } \\
\text { tikka. }{ }^{22}\end{array}$ & $\begin{array}{l}\text { Questo è un nuovo ristorante, } \\
\text { abbiamo aperto oggi. È un } \\
\text { ristorante indiano. Ottimo cibo. } \\
\text { Pollo tikka. }\end{array}$ \\
\hline
\end{tabular}

22. Grilled chicken pieces in tomato puree sautéed with onions and other spices, and garnished with fresh green coriander. 
Chicken tikka is indeed often celebrated, throughout the whole film, as one of the most typical symbols of Indian culinary, and therefore socio-cultural, traditions that should be made known worldwide; this is highlighted, for instance, when Madame Mallory visits the Maison Mumbai for the first time and asks what type of oven that in the yard is, and Mansur explains that it is a type of oven specifically designed to cook this special Indian dish (see example 17).

Example 17. The Hundred-Foot Journey (00:30:47)

\begin{tabular}{|l|l|l|}
\hline $\begin{array}{l}\text { MADAME } \\
\text { MALLORY }\end{array}$ & Mmm. What is this? & Mmm. Cos'è questo? \\
\hline MANSUR & It is an oven. & È un forno? \\
\hline $\begin{array}{l}\text { MADAME } \\
\text { MALLORY }\end{array}$ & $\begin{array}{l}\text { Oven? It's not a drum? To } \\
\text { play? }\end{array}$ & $\begin{array}{l}\text { Forno? Non è una grancassa per } \\
\text { suonare? }\end{array}$ \\
\hline MANSUR & $\begin{array}{l}\text { No. Tandoori oven for chicken } \\
\text { tikka. }\end{array}$ & $\begin{array}{l}\text { No. È il forno tandoori per il pollo } \\
\text { tikka. }\end{array}$ \\
\hline
\end{tabular}

The fact that, with the opening of their Maison Mumbai, the Kadams want to recreate the environment they have left behind is also proved by their getting spices directly from India, as they see this as a further means to keep their Indian identity alive: in this sense, every bite of the food they eat is like a bite of home, as Hassan says when talking to an Indian cook in Paris (see example 18), a figurative connotation that is maintained also in dub (see section 4 for an analysis of the figurative use of language linked to food to ascribe identity to the ethnic characters).

Example 18. The Hundred-Foot Journey (01:43:32)

\begin{tabular}{|l|l|l|}
\hline HASSAN & Where did she get the spices? & Dove ha preso le spezie? \\
\hline COOK & $\begin{array}{l}\text { I have them send it from home, } \\
\text { from India. You know, it's cheaper } \\
\text { than a flight ticket. }\end{array}$ & $\begin{array}{l}\text { Me le faccio mandare da casa, } \\
\text { dall'India. Lo sa, costa meno di un } \\
\text { biglietto aereo. }\end{array}$ \\
\hline HASSAN & It's got amchur. $^{23}$ & C'è l'amchur. \\
\hline COOK & Yes. & Si. \\
\hline HASSAN & And kala jeera. ${ }^{24}$ & E il kala jeera. \\
\hline COOK & $\begin{array}{l}\text { Yes. A little bit of garam masala }{ }^{25} \\
\text { also. Every bite takes you home. }\end{array}$ & $\begin{array}{l}\text { Si. E anche un po' di garan masala. } \\
\text { Ogni boccone ti riporta a casa. }\end{array}$ \\
\hline
\end{tabular}

23. Mango powder.

24. Black cumin.

25. Blend of ground spices. 


\subsection{Food and "otherness"}

What we have observed so far significantly underlines how ethnic food acts as a crucial marker of differentiation between European/American and non-European/American cultures. This is especially to be noticed in My Big Fat Greek Wedding, where food functions as the main vehicle for the expression of difference and "otherness" as embodied by Toula Portokalos and her family. At the beginning, Toula recollects her childhood through food scenes, pointing out how she always felt different also in relation to her family's foodways (see example 19).

Example 19. My Big Fat Greek Wedding (00:02:24)

\begin{tabular}{|l|l|l|}
\hline $\begin{array}{l}\text { TOULA } \\
\text { (VOICE) }\end{array}$ & $\begin{array}{l}\text { When I was growing up I knew } \\
\text { I was different, the other girls } \\
\text { were blond and delicate and I } \\
\text { was a swarthy six-year-old with } \\
\text { sideburns. I so badly wanted } \\
\text { to be like the popular girls, all } \\
\text { sitting together, talking and } \\
\text { eating their Wonder Bread } \\
\text { Sandwiches... }\end{array}$ & $\begin{array}{l}\text { Quando ero piccola sapevo di } \\
\text { essere diversa. Le altre bambine } \\
\text { erano biondine e delicate mentre } \\
\text { io... ero una morettona di sei } \\
\text { anni con i basettoni. Mi sarei } \\
\text { dannata per essere come le } \\
\text { ragazze ben volute da tutti, che } \\
\text { sedevano insieme a parlare e a } \\
\text { mangiare i loro panini con il pane } \\
\text { a cassetta... }\end{array}$ \\
\hline LITTLE GIRL & What's that? & E quello cos'è? \\
\hline TOULA & Moussakă.26 & Moussakà. \\
\hline LITTLE GIRL & Mous-kaka?? & Mous-kaka?? \\
\hline
\end{tabular}

In this scene, we see the young Toula at school, eating her lunch of moussaka at a table by herself while at the next table the popular American girls - white, blond, thin, pretty - are eating Wonder bread sandwiches, the all-American food: the girls make fun of Toula's lunch and one deliberately mispronounces it as "moose ka-ka", where "kaka" is a child's word referring to feces, something that assigns negative connotations to Toula's "different" food and implicitly to her. This image and the figurative connotations it implies, maintained also in dub, place a stark distinction between what is American, i.e. white Wonder Bread sandwiches, and what is not, i.e. Greek moussaka. This is also how we learn that Toula is not completely comfortable with her Greek identity and wishes to assimilate and be like the American girls.

26. It is an eggplant and/or potato-based dish popular in Balkan and Mediterranean cuisines, with many local and regional variations. 
The relevance of food as a symbol of "otherness" can also be noticed when the Portokaloses meet the parents of Toula's American husband-to-be. The distance between the two cultures is particularly emphasized during the first dinner together at the Portokaloses: the Millers are continuously offered food such as spanakopita, typically served during social occasions but certainly not the most suitable one to guests who are the stereotypical WASP (White, AngloSaxon and Protestant) family, and look almost disgusted when presented with its greasy slices (see example 20).

Example 20. My Big Fat Greek Wedding (01:05:48)

\begin{tabular}{|c|c|c|}
\hline $\begin{array}{l}\text { VOULA TO } \\
\text { IAN'S PARENTS }\end{array}$ & $\begin{array}{l}\text { Spanakopita! You're } \\
\text { hungry? }\end{array}$ & Spanakopita! Avete fame? \\
\hline IAN'S FATHER & Thank you. & Grazie. \\
\hline
\end{tabular}

Immediately after this, the Millers are pushed upon countless shots of ouzo, a typical Greek liquor which soon intoxicates them (see example 21).

Example 21. My Big Fat Greek Wedding (01:06:13)

\begin{tabular}{|l|l|l|}
\hline WOMAN & Rodney, Henriette, ouzo? & Rodney, Henriette, ouzo? \\
\hline IAN'S FATHER & Thank you. Oh, it's licorice. & Grazie. Oh, è liquerizia. \\
\hline
\end{tabular}

Also in My Big Fat Greek Wedding 2 the Greek characters' "otherness" is highlighted from the beginning, for instance when Gus' nephew Costa, a third-generation Greek, mentions "spanakopita" curiously declaring that the American spellcheck changes it to "spina bifida", thus pointing out that Greek food is often considered, within American culture, as something "different" in the negative sense of the term (see example 22).

Example 22. My Big Fat Greek Wedding 2 (00:04:16)

\begin{tabular}{|l|l|l|}
\hline COSTA & $\begin{array}{l}\text { Oh no, spellcheck corrected } \\
\text { spanakopita to spina bifida. }\end{array}$ & $\begin{array}{l}\text { Oh no, il correttore ortografico ha } \\
\text { corretto spanakopita in spina bifida. }\end{array}$ \\
\hline
\end{tabular}

Similarly, in My Life in Ruins, Greek culture is often presented as opposed to European and American culture through food images: when Georgia offers her tourists some souvlaki, ${ }^{27}$ they initially reject it preferring the "chicken

27. A Greek dish of pieces of meat grilled on a skewer. 
fingers and French fries" served by an everything-but-Greek Hard Rock Café (see example 23).

Example 23. My Life in Ruins (00:19:24)

\begin{tabular}{|l|l|l|}
\hline GEORGIA & It's souvlaki. It's meat on a stick. & Sono souvlaki. Spiedini di carne. \\
\hline$[\ldots]$ & & \\
\hline NICO & $\begin{array}{l}\text { Hey, hey. Come to the Hard Rock } \\
\text { Café. It's very Greek. }\end{array}$ & $\begin{array}{l}\text { Hey, hey. Venite all'Hard Rock } \\
\text { Café. Tipico greco. }\end{array}$ \\
\hline GATOR & $\begin{array}{l}\text { Yeah, Hard Rock! Chicken fingers } \\
\text { and French fries! }\end{array}$ & $\begin{array}{l}\text { Sì, Hard Rock! Io vado, ho voglia } \\
\text { di patatine fritte. }\end{array}$ \\
\hline$[\ldots]$ & & $\begin{array}{l}\text { No, no. Ho preso i souvlaki, perchè } \\
\text { volete andare in quel... }\end{array}$ \\
\hline GEORGIA & $\begin{array}{l}\text { Nould you want to that... } \\
\text { wouvlaki, why }\end{array}$ & \multicolumn{2}{|l}{} \\
\hline
\end{tabular}

In this case, American fast-food culture seems to win over traditional Greek culinary culture, though the reference to souvlaki is nevertheless given a particular emphasis as Georgia waves a stick of this specialty in her hand while pronouncing its name, thus visually and linguistically stressing its being an important mark of Greek ethnicity.

Another film that extensively examines cultural differences through food is The Hundred-Foot Journey. In one of the first scenes, Mr. Kadam celebrates Indian cuisine as superior to French cuisine making a list of typical Indian dishes that the President of France could certainly never taste at the Le Saule Pleureur, though this is one of the best French restaurants in the area (see example 24).

Example 24. The Hundred-Foot Journey (00:19:37)

\begin{tabular}{|l|l|l|}
\hline MR. KADAM & $\begin{array}{l}\text { Is the President of France able } \\
\text { to order murgh masala, } \\
\text { cashew nuts and cardamom? } \\
\text { And ka saag aloo }{ }^{29} \text { Dhal? Our } \\
\text { secret family spices? }\end{array}$ & $\begin{array}{l}\text { E il Presidente della Francia può } \\
\text { ordinare un murgh masala, con } \\
\text { anacardi e cardamomo? O un ka } \\
\text { saag aloo? O un dhal? Con le spezie } \\
\text { segrete di famiglia? }\end{array}$ \\
\hline MANSUR & $\begin{array}{l}\text { No, but they are a Michelin } \\
\text { star restaurant, Papa. }\end{array}$ & $\begin{array}{l}\text { No, ma è un ristorante con una } \\
\text { stella Micheline, Papa. }\end{array}$ \\
\hline AISHA & $\begin{array}{l}\text { They have frogs' legs, escargot, } \\
\text { ratatouille... }\end{array}$ & $\begin{array}{l}\text { Fanno zampe di rana, escargot, } \\
\text { ratatouille... }\end{array}$ \\
\hline
\end{tabular}

28. Spicy, sweet, rich chicken curry.

29. Potato dish. 


\begin{tabular}{|l|l|l|}
\hline MR. KADAM & $\begin{array}{l}\text { Is the President able to order } \\
\text { tandoori goat? Cooked the way } \\
\text { Hassan cooks? Sprinkled with } \\
\text { roast spices? }\end{array}$ & $\begin{array}{l}\text { E il Presidente può ordinare il } \\
\text { capretto tandoori? Come lo cucina } \\
\text { Hassan? Cosparso di spezie tostate? }\end{array}$ \\
\hline
\end{tabular}

\subsection{Food as a means of integration}

If in these films ethnic food is used as a marker of cultural differentiation, it is also used to reconcile the clash between two cultures, creating affective bonds across cultural difference.

In My Big Fat Greek Wedding, a crucial event contributing to cultural integration occurs at the end when Toula's father gives a speech at the wedding reception and explains that the name "Miller" comes from the Greek word milo, which means "apple", and that the name Portokalos comes from the Greek word portokali, which means "orange" (see example 25).

Example 25. My Big Fat Greek Wedding (01:21:47)

\begin{tabular}{|c|c|c|}
\hline $\begin{array}{l}\text { TOULA'S } \\
\text { FATHER }\end{array}$ & $\begin{array}{l}\text { I was thinking last night ... the } \\
\text { night before my daughter was } \\
\text { going to marry Ian Miller ... that } \\
\text { the root of the word "miller" } \\
\text { is a Greek word. And "miller" } \\
\text { come from the Greek word milo, } \\
\text { which is mean "apple." There } \\
\text { you go. As many of you know, } \\
\text { our name Portokalos is come } \\
\text { from the Greek word portokali, } \\
\text { which means "orange." So, okay } \\
\text { here tonight, we have apple and } \\
\text { orange. We all different but, in } \\
\text { the end, we all fruit. }\end{array}$ & $\begin{array}{l}\text { Stavo pensando ieri sera... la sera } \\
\text { prima che mia figlia si sposa con } \\
\text { Ian Miller... che... insomma... } \\
\text { la radice della parola "Miller" } \\
\text { è un parola greca. E "Miller" } \\
\text { viene dalla parola greca milo, } \\
\text { che significa "mela". Ed ecco } \\
\text { qua. Come molti di voi sanno, } \\
\text { il nostro cognome Portokalos } \\
\text { viene dalla parola greca portokali, } \\
\text { che significa "arancia". Dunque, } \\
\text { allora, qui stasera abbiamo mela } \\
\text { e arancia. Siamo tutti diversi ma } \\
\text { alla fine siamo tutti frutta. }\end{array}$ \\
\hline
\end{tabular}

This is a clear reference to the American proverb "to compare apples and oranges", which is used to describe a situation where two things are incomparable as they are completely different. However, Toula's father reverses this by asserting that, in the end, they are "all fruit", i.e. they are all human beings belonging to the same social reality irrespective of their different ethnic background and that, therefore, they can coexist and find commonalities in order to form a happy family.

In this film, a further proof of food symbolic power to dissolve intercultural conflicts can be observed when Ian's mother, during the wedding reception, states that she needs to drink some more ouzo - the Greek liquor she hated 
when she first tasted it - to get the courage to dance with her "new" family (see example 26).

Example 26. My Big Fat Greek Wedding (01:24:37)

\begin{tabular}{|l|l|l|}
\hline $\begin{array}{l}\text { TOULA TO IAN'S } \\
\text { MOTHER }\end{array}$ & $\begin{array}{l}\text { Let's go dance now, come } \\
\text { on. }\end{array}$ & Ora si balla, coraggio. \\
\hline IAN'S MOTHER & $\begin{array}{l}\text { Oh no, I need some more } \\
\text { ouzo before I do that. }\end{array}$ & $\begin{array}{l}\text { Oh no, ho bisogno di un altro po' di } \\
\text { ouzo prima di arrivare a quello. }\end{array}$ \\
\hline
\end{tabular}

Accepting to drink ouzo, she implicitly accepts Toula as her daughter-in-law: she now proves to be willing to inject herself into another culture and therefore to taste other types of food, thus also establishing an emotional connection with the people representing such "otherness".

In My Life in Ruins Greek food acts as a symbol of acceptance of the "otherness" it initially represents when, in the concluding scene, the European and American tourists and the Greek people working within the Greek tourist industry gather for a farewell dinner. All types of Greek food are served and two American tourists express their appreciation for some delicious Greek specialties, the same specialties they rejected upon their arrival in Greece (see example 27).

Example 27. My Life in Ruins (01:24:06)

\begin{tabular}{|l|l|l|}
\hline BIG AL & $\begin{array}{l}\text { Great buffet, Angie. These baklavas are } \\
\text { a riot. }\end{array}$ & $\begin{array}{l}\text { Magnifico il buffet, Angie. Queste } \\
\text { baklava sono da urlo. }\end{array}$ \\
\hline KIM & $\begin{array}{l}\text { I've got benecoupola } 30 \text { and dolmadas } \\
\text { and they look very good. Or, as they } \\
\text { say in Greek, kali kola. }\end{array}$ & $\begin{array}{l}\text { Angie, io ho preso un po' di } \\
\text { benecoupola i dolmadas e sembra } \\
\text { tutto molto buono, o come dicono } \\
\text { in Grecia, kali kola. }\end{array}$ \\
\hline
\end{tabular}

A film that clearly highlights the function food has of blending both cultures and languages is The Hundred-Foot Journey, where French and Indian cultures blend just through cooking: if food initially divides, then it definitely brings people together, uniting two seemingly unequivocally different cultures. The whole film is indeed permeated with a sense of necessary compromises in socio-cultural and linguistic values, as the food scenes, as well as the naming of food original names, set up and resolve clashes between the two worlds. Food significantly acts as a powerful means of integration, for instance, when

30. Beef tenderloin.

31. Stuffed grape leaves. 
Marguerite asks Hassan what his favorite dish to cook is: in answering that it is jalebi, he explains what this typical Indian food consists of and adds further emotional connotations when he says that it reminds him of his mother, thus stressing the figurative role played by food of recalling cultural, and linguistic, memories of the heart (see example 28).

Example 28. The Hundred-Foot Journey (00:47:26)

\begin{tabular}{|l|l|l|}
\hline MARGUERITE & $\begin{array}{l}\text { What's your favorite dish to } \\
\text { cook? }\end{array}$ & Qual è il piatto che ami cucinare? \\
\hline HASSAN & Jalebi. & Lo jalebi. \\
\hline MARGUERITE & What is that? & E che cos'è? \\
\hline HASSAN & $\begin{array}{l}\text { Fermented dal and flour, deep } \\
\text { fried. }\end{array}$ & $\begin{array}{l}\text { Dal fermentato e farina, tutto } \\
\text { fritto. }\end{array}$ \\
\hline MARGUERITE & Mmm... & Mmm... \\
\hline HASSAN & $\begin{array}{l}\text { The smell reminds me of my } \\
\text { mother. [...] Food is memories. }\end{array}$ & $\begin{array}{l}\text { Il profumo mi fa pensare a } \\
\text { mia madre. [...] I piatti sono } \\
\text { memoria. }\end{array}$ \\
\hline
\end{tabular}

In this film, the process of culinary, and therefore cultural, integration is primarily carried on by Hassan, always adding Indian ingredients to French dishes, and it is definitely celebrated when some food critics write enthusiastic reviews of the culinary regeneration he has brought about, transforming French cuisine and creating unusual but tasty combinations with his introduction of Indian bold spices (see examples 29-30).

Example 29. The Hundred-Foot Journey (01:37:14)

\begin{tabular}{|l|l|l|}
\hline FOOD & While it's only been a few \\
CRITIC 1 & $\begin{array}{l}\text { Eranths passati solo pochi mesi } \\
\text { was pleasantly surprised by } \\
\text { the appearance of coriander, } \\
\text { fenugreek and masala. }\end{array}$ & $\begin{array}{l}\text { dalla mia ultima visita ma sono } \\
\text { rimasto piacevolmente sorpreso } \\
\text { dall'apparizione di coriandolo, fieno } \\
\text { greco e masala. }\end{array}$ \\
\hline
\end{tabular}

Example 30. The Hundred-Foot Journey (01:37:22)

\begin{tabular}{|c|c|c|}
\hline $\begin{array}{l}\text { FOOD } \\
\text { CRITIC } 2\end{array}$ & $\begin{array}{l}\text {...glutinous sauce resonant of } \\
\text { tandoori and this was a surprising } \\
\text { triumph... }\end{array}$ & $\begin{array}{l}\text {...una salsa gelatinosa con sentori di } \\
\text { tandoori ed è stato un sorprendente } \\
\text { trionfo... }\end{array}$ \\
\hline
\end{tabular}

Another film that particularly celebrates the (also linguistic) intermingling of two cultures as figuratively allowed by food is The Mistress of Spices. Here the Indian spices act as the main protagonists, symbolizing tradition and identity, 
endowed with the power to heal and to harm, to please and to punish, to create and to destroy and even to reorganize the world order while constantly supporting their Mistress Tilo, significantly named after the spice of nourishment (see example 31).

Example 31. The Mistress of Spices (00:04:24)

\begin{tabular}{|l|l|l|}
\hline TILO & $\begin{array}{l}\text { The spices are my love. [...] I am } \\
\text { named Tilo, after the sesame seeds, the } \\
\text { spice of nourishment. }\end{array}$ & $\begin{array}{l}\text { Le spezie sono il mio grande amore. } \\
{[\ldots] \text { Io mi chiamo Tilo, nella mia }} \\
\text { lingua vuol dire semi di sesamo, la } \\
\text { spezia del nutrimento. }\end{array}$ \\
\hline
\end{tabular}

As Tilo "is" the spice of nourishment, she "feeds" her Indian and American customers' needs with the help of the magical powers of the spices, thus also bridging the gap between the complex culinary science of India and the American fast-food consumption culture. In this film the spices rest upon the shop shelves as dull objects but often come to life and act as proper characters, with the potential to influence the course of events: indeed, in many scenes Tilo "awakens" them, addressing them by their original Indian names and explaining their mystical properties to some of her regular customers (see examples 32-35).

Example 32. The Mistress of Spices (00:05:55)

\begin{tabular}{|l|l|l|}
\hline TILO & $\begin{array}{l}\text { He was nervous that day so I just } \\
\text { gave him some brahmi leaves to } \\
\text { chaw. }\end{array}$ & $\begin{array}{l}\text { Quel giorno era nervoso così gli ho dato } \\
\text { foglie di brahmi da masticare. }\end{array}$ \\
\hline
\end{tabular}

Example 33. The Mistress of Spices (00:06:01)

\begin{tabular}{|l|l|l|}
\hline HAROUN & $\begin{array}{l}\text { Yeah, but for the first time he } \\
\text { remembered the Swearing to the } \\
\text { Flag, in English. }\end{array}$ & $\begin{array}{l}\text { Sì, ma per la prima volta si è ricordato } \\
\text { il Giuramento alla Bandiera, addirittura } \\
\text { in inglese. }\end{array}$ \\
\hline TILO & $\begin{array}{l}\text { It wasn't me, it was the dashmool, } \\
\text { the herb of ten roots. }\end{array}$ & $\begin{array}{l}\text { Non sono stata io. È stato il dashmool, } \\
\text { l'erba dalle 10 radici. }\end{array}$ \\
\hline
\end{tabular}

Example 34. The Mistress of Spices (00:07:05)

\begin{tabular}{|l|l|l|}
\hline $\begin{array}{l}\text { TILO } \\
\text { (VOICE) }\end{array}$ & $\begin{array}{l}\text { Chandan, the powder of the } \\
\text { sandalwood tree, that relieves the } \\
\text { pain of remembering. }\end{array}$ & $\begin{array}{l}\text { Chandan, la polvere dell'albero di } \\
\text { sandalo, che allevia il dolore dei } \\
\text { brutti ricordi. }\end{array}$ \\
\hline
\end{tabular}




\section{Example 35. The Mistress of Spices (00:24:30)}

\begin{tabular}{|l|l|l|}
\hline $\begin{array}{l}\text { TILO } \\
\text { (VOICE) }\end{array}$ & $\begin{array}{l}\text { What does Haroun need? Kalo } \\
\text { jire, black cumin seeds, protection } \\
\text { against the evil eye. Thank you, } \\
\text { spices. }\end{array}$ & $\begin{array}{l}\text { Di cosa ha bisogno Haroun? Kalo } \\
\text { jire, semi neri di cumino, protezione } \\
\text { dall'occhio malvagio. Grazie, spezie. }\end{array}$ \\
\hline
\end{tabular}

Tilo also often teaches her customers some typical Indian recipes that are said to be aphrodisiacs, such as coconut korma (see example 36) and baingan bharta (see example 37).

Example 36. The Mistress of Spices (00:14:16)

\begin{tabular}{|l|l|l|}
\hline TILO & You're cooking for her again? & Cucini ancora per lei? \\
\hline KWESI & She loved the coconut korma. & È impazzita per il korma al cocco. \\
\hline $\begin{array}{l}\text { TILO } \\
\text { (VOICE) }\end{array}$ & $\begin{array}{l}\text { There's nothing like its delicate } \\
\text { flesh to unite two hearts. }\end{array}$ & $\begin{array}{l}\text { Non c'è niente come la sua carne } \\
\text { delicata per unire due cuori. }\end{array}$ \\
\hline
\end{tabular}

Example 37. The Mistress of Spices (00:14:40)

\begin{tabular}{|l|l|l|}
\hline TILO & ... You should try the baingan & .. Dovresti provare la baingan bharta. \\
& bharta. You grill the eggplant over & Arrostisci la melanzana su una fiamma, \\
& a flame, sculpt the inside out and & tiri fuori la polpa e poi la friggi con \\
& then fry it with ten cloves of garlic, & dieci spicchi d'aglio, semi di cumino, \\
& cumin seeds, little red onions and & cipolline rosse e pomodori. E una \\
& tomatoes. And you sprinkle it with & spolverata di foglie di coriandolo. \\
& coriander leaves. (voice) To feed & (voice) Per tenere viva la passione per \\
your passion through the night. & tutta la notte. \\
\hline
\end{tabular}

She explains the positive effects paan ${ }^{32}$ and supari $^{33}$ can have for couples (see example 38) and she gives garan masala to sad and depressed hearts to give them hope again (see example 39).

\section{Example 38. The Mistress of Spices (00:44:30)}

\begin{tabular}{|c|c|c|}
\hline $\begin{array}{l}\text { TILO } \\
\text { TO } \\
\text { KWESI }\end{array}$ & $\begin{array}{l}\text { I have got something for you } \\
\text { today. Paan, a must at the end of } \\
\text { every couple's meal. What else } \\
\text { here... is... sticks of supari for } \\
\text { intoxication... }\end{array}$ & $\begin{array}{l}\text { Ho una cosa che fa per te oggi. Paan, } \\
\text { indispensabile alla fine di ogni pasto } \\
\text { di una coppia. Dunque... ci mettiamo, } \\
\text { guarda...bastoncini di supari per } \\
\text { l'ebbrezza... }\end{array}$ \\
\hline
\end{tabular}

32. A preparation combining betel leaf with areca nut and sometimes also with tobacco, chewed for its stimulant and psychoactive effects.

33. Areca nut. 
Example 39. The Mistress of Spices (00:49:37)

\begin{tabular}{|l|l|l|}
\hline $\begin{array}{l}\text { TILO } \\
\text { (VOICE) }\end{array}$ & $\begin{array}{l}\text { I'll give her a special blend of } \\
\text { garan masala, for hope. }\end{array}$ & $\begin{array}{l}\text { Le darò una miscela speciale di garan } \\
\text { masala, per la speranza. }\end{array}$ \\
\hline
\end{tabular}

Things change when Tilo falls in love with Doug, an American guy; indeed, as the spices represent tradition, and tradition is resistant to change, so are the spices and they put up resistance when Tilo seems to choose Doug over them, breaking the rule of absolute devotion to them. They thus refuse to tell Tilo what Doug's spice is when she asks them for advice as she first talks to the man in her shop (see example 40).

Example 40. The Mistress of Spices (00:28:23)

\begin{tabular}{|l|l|l|}
\hline TILO & Everyone has a spice. & Ognuno ha una sua spezia. \\
\hline DOUG & $\begin{array}{l}\text { Really? I've got a spice, too? And } \\
\text { which one is mine? }\end{array}$ & $\begin{array}{l}\text { Davvero? Ne ho una anch'io? E qual è } \\
\text { la mia? }\end{array}$ \\
\hline $\begin{array}{l}\text { TILO } \\
\text { If you wait here a minute, I'll just } \\
\text { speak to me. What does he need? } \\
\begin{array}{l}\text { Is it Methi seeds for strength? } \\
\text { Ajwain for confidence? Fennel for } \\
\text { perseverance? Why I cannot see? } \\
{[\ldots] \text { Asafetida the antidote to love. }} \\
\text { You can't be his spice. }\end{array}\end{array}$ & $\begin{array}{l}\text { Beh, se aspetta un attimo la vado a } \\
\text { cercare. (voice) Spezie, parlatemi. Di } \\
\text { che cosa ha bisogno? Semi di Methi } \\
\text { per la forza? Semi di Ajwain per la } \\
\text { sicurezza in se stesso? Finocchio per } \\
\text { la perseveranza? Perché non riesco } \\
\text { a vedere? [...] Asafetida. Lantidoto } \\
\text { all'amore. Non puoi essere tu la sua } \\
\text { spezia. }\end{array}$ \\
\hline
\end{tabular}

Without any help from the spices, Tilo gives Doug an herb, tulsi, which she knows has only the power to remind him to go back to her (see example 41), though aware that if only she could use another special spice, prishniparni something that is instead forbidden as she cannot exploit the power of the spices to her own ends - she would certainly have him back (see example 42).

Example 41. The Mistress of Spices (00:30:44)

\begin{tabular}{|l|l|l|}
\hline TILO & $\begin{array}{l}\text { I'm all out of your spice but... I } \\
\text { have something for you. }\end{array}$ & $\begin{array}{l}\text { Io avrei finito la sua spezia però } \\
\text { aspetti... qui ho qualcosa per lei }\end{array}$ \\
\hline DOUG & What is it? & Che cos'è? \\
\hline TILO & This is ... tulsi, holy basil. & Questo è... tulsi, basilico santo. \\
\hline DOUG & What's for? & A che serve? \\
\hline TILO & $\begin{array}{l}\text { Drink it like tea. And that's on the } \\
\text { house. }\end{array}$ & $\begin{array}{l}\text { Lo prepari come il tè. Glielo offre la } \\
\text { casa. }\end{array}$ \\
\hline$[\ldots]$ & & \\
\hline
\end{tabular}




\begin{tabular}{|l|l|l|}
\hline $\begin{array}{l}\text { TILO } \\
\text { (VOICE) }\end{array}$ & $\begin{array}{l}\text { Tulsi, for remembering. } \\
\text { Remember to come back. }\end{array}$ & $\begin{array}{l}\text { Tulsi, per ricordare. Ricordarsi di } \\
\text { tornare. }\end{array}$ \\
\hline
\end{tabular}

Example 42. The Mistress of Spices (00:33:37)

\begin{tabular}{|c|c|c|}
\hline $\begin{array}{l}\text { TILO } \\
\text { (VOICE) }\end{array}$ & $\begin{array}{l}\text { It would be so easy, just once, to } \\
\text { use the spices for myself. Mushed } \\
\text { Prishniparni, burnt with loto's roots } \\
\text { in the evening, would make him } \\
\text { come back to me. }\end{array}$ & $\begin{array}{l}\text { Sarebbe così facile, per una sola } \\
\text { volta, usare le spezie per me stessa. } \\
\text { Prishniparni schiacciata, bruciata con } \\
\text { radici di loto la sera, lo farebbero } \\
\text { tornare da me. }\end{array}$ \\
\hline
\end{tabular}

All the previous examples clearly illustrate that Tilo's Spice Bazaar is metaphoric of the Indian presence in the world: the spices and their names become the Indian means of constructing a multicultural and multilingual world, within which the boundaries between cultures and languages are blurred and ethnic differences dissolve.

\subsection{Food and feelings}

The emotional connotations assigned to Tilo's spices in The Mistress of Spices lead us to point out that, in our corpus of films, ethnic food is also seen as a perfect vehicle for emotional manifestations. Indeed, feelings are often kneaded into food and intercultural passions find shape in tasting food typically belonging to the other's culinary traditions. This can be observed, for instance, in Ae Fond Kiss when Casim, a Glaswegian DJ of Pakistani origins, offers Roisin, the Irish Catholic girl he is in love with, some glab jamin, a popular dessert in India and Pakistan,$^{34}$ in the attempt to assimilate the girl into his own cultural heritage teaching her something of his own foodways, also from the linguistic point of view (see example 43).

Example 43. Ae Fond Kiss (01:04:09)

\begin{tabular}{|l|l|l|}
\hline CASIM & Here you go, Miss Hanlon. & Ecco a lei, signorina professoressa. \\
\hline ROISIN & Ooh, lovely! & Oh, che bello! \\
\hline CASIM & Glab jamin and ice cream. & Glab jamin con il gelato. \\
\hline ROISIN & Glab jammin. & Glab jami? \\
\hline CASIM & No, glab jamin and ice cream. & No, si dice glab jamin con gelato. \\
\hline
\end{tabular}

34. Also known as "waffle balls", it is made of dough, often including double cream and a little flour in a sugar syrup flavored with cardamom, rosewater or saffron. 


\begin{tabular}{|l|l|l|}
\hline ROISIN & $\begin{array}{l}\text { Jamin, thanks very much. What } \\
\text { is it? }\end{array}$ & Grazie, ma che cos'è? \\
\hline CASIM & Glab jamin and ice cream. & Glab jamin con il gelato. \\
\hline
\end{tabular}

Similarly, in Eat Pray Love, when Felipe and Liz are at Bali local market, he offers her rambutan, fruits from Southeastern Asia similar to lychees (see example 44).

Example 44. Eat Pray Love (01:44:58)

\begin{tabular}{|l|l|l|}
\hline FELIPE & $\begin{array}{l}\text { These are rambutan. They're } \\
\text { delicious. It's like an orange made } \\
\text { love to a plum. Would you like } \\
\text { some? }\end{array}$ & $\begin{array}{l}\text { Questi sono rambutan. Una delizia. } \\
\text { E come se un'arancia avesse fatto } \\
\text { l'amore con una prugna. Li vuoi } \\
\text { assaggiare? }\end{array}$ \\
\hline
\end{tabular}

As these exotic fruits are unknown in Western countries, Felipe tries to explain to Liz how they taste using a simile (rendered also in dub) that has amorous connotations, thus figuratively projecting on food the love expectations he has of the woman.

\subsection{Food as therapy}

Many of the films under study also often highlight the healing power of ethnic food. For instance, in Eat Pray Love, when Liz is in Bali, she is offered by Wayan, the local town healer, some jamu, a traditional Indonesian medicine made from parts of plants like roots, barks, flowers, seeds, leaves and fruits and commonly used by herbal practitioners as a form of therapy to maintain good health and to treat diseases (see example 45).

Example 45. Eat Pray Love (01:36:19)

\begin{tabular}{|l|l|l|}
\hline WAYAN & $\begin{array}{l}\text { Jamu. Drink this. Better than } \\
\text { antibiotic. }\end{array}$ & Jamu. Bevi. Meglio che antibiotico. \\
\hline
\end{tabular}

Similarly, in The Mistress of Spices, when Doug goes back to Tilo after his mother's death, she offers him some nimbu pani to relieve his sufferings (see example 46).

Example 46. The Mistress of Spices (00:51:54)

\begin{tabular}{|l|l|l|}
\hline $\begin{array}{l}\text { TILO } \\
\text { TO } \\
\text { DOUG }\end{array}$ & $\begin{array}{l}\text { I'll give you a nimbu pani, a lime soda. } \\
\text { It'll cool you down. }\end{array}$ & $\begin{array}{l}\text { Ti porto un nimbu pani, una bibita } \\
\text { al lime, ti calmerà i nervi. }\end{array}$ \\
\hline
\end{tabular}




\section{Building ethnicity through the figurative power of food}

In many of the films under study, the identity of the immigrant characters is shaped not only by their recurrent use of code-switching when quoting the we-code names of their home culinary specialties, but also by a peculiar use of figurative language related to food, a linguistic device that further contributes to mold the ethnic self and is always re-created in the Italian dubbed versions.

This can be observed, for instance, in The Hundred Foot Journey, where the Indian characters recurrently associate food to the essence of life, as we can see when Hassan's mother, teaching his son to cook, compares the taste of sea urchins to the taste of life itself (see example 47).

Example 47. The Hundred Foot Journey (00:03:53)

\begin{tabular}{|l|l|l|}
\hline $\begin{array}{l}\text { HASSAN'S } \\
\text { MOTHER }\end{array}$ & $\begin{array}{l}\text { The sea urchins taste of life, don't } \\
\text { you think? }\end{array}$ & $\begin{array}{l}\text { I ricci di mare sanno di vita, non } \\
\text { lo credi anche tu? }\end{array}$ \\
\hline HASSAN & Mmm... & Mmm... \\
\hline $\begin{array}{l}\text { HASSAN'S } \\
\text { MOTHER }\end{array}$ & $\begin{array}{l}\text { Life has its own flavor, hidden in } \\
\text { that shell. Raw, beautiful life. }\end{array}$ & $\begin{array}{l}\text { La vita ha un suo sapore, nascosto } \\
\text { in quella conchiglia. Vita cruda e } \\
\text { meravigliosa. }\end{array}$ \\
\hline
\end{tabular}

What is interesting to notice in this film is that food is figuratively used as a symbol of identity both for the Indian characters and for people belonging to other nationalities, as when Hassan states that in England vegetables have "no soul", implicitly referring to the coldness and stiffness typical of the British (see example 48).

Example 48. The Hundred Foot Journey (00:07:15)

\begin{tabular}{|l|l|l|}
\hline $\begin{array}{l}\text { CUSTOMS } \\
\text { AGENT }\end{array}$ & $\begin{array}{l}\text { And why exactly are you leaving } \\
\text { London? }\end{array}$ & $\begin{array}{l}\text { Per quale motivo ha deciso di } \\
\text { lasciare Londra? }\end{array}$ \\
\hline HASSAN & $\begin{array}{l}\text { I found in England that the } \\
\text { vegetables, they had no... had no } \\
\text { soul. No life. }\end{array}$ & $\begin{array}{l}\text { Ho scoperto che in Inghilterra le } \\
\text { verdure non hanno... non hanno } \\
\text { un'anima. Non hanno vita. }\end{array}$ \\
\hline
\end{tabular}

Also in My Big Fat Greek Wedding some rhetorical figures linked to food are employed to give a peculiar portrayal of the food-obsessed Portokalos family; this can be seen, for example, when Toula recollects some memories of her childhood and says that her mother used food as a sort of educational tool for her children (see example 49). 
Example 49. My Big Fat Greek Wedding (00:03:26)

\begin{tabular}{|l|l|l|}
\hline $\begin{array}{l}\text { TOULA } \\
\text { (VOICE) }\end{array}$ & $\begin{array}{l}\text { My mom was always cooking foods } \\
\text { filled with warmth and wisdom... } \\
\text { and never forgetting that side dish of } \\
\text { steaming-hot guilt. }\end{array}$ & $\begin{array}{l}\text { Mia mamma non faceva che } \\
\text { cucinare pietanze piene di calore } \\
\text { e saggezza... senza dimenticare } \\
\text { il contorno fumante di sensi di } \\
\text { colpa. }\end{array}$ \\
\hline $\begin{array}{l}\text { TOULA'S } \\
\text { MOTHER }\end{array}$ & $\begin{array}{l}\text { Niko, don't play with the food. When } \\
\text { I was your age, we didn't have food. }\end{array}$ & $\begin{array}{l}\text { Niko, non si gioca con il mangiare. } \\
\text { Alla vostra età non avevo da } \\
\text { mangiare io. }\end{array}$ \\
\hline
\end{tabular}

Here "warmth and wisdom" appear to be the main ingredients of the dishes prepared by Maria Portokalos, who also serves "guilt" as a side dish in order to teach her children not to waste food, as it is something that, according to her and to her Greek socio-cultural backdrop, should be always valued highly.

In this film, food is used figuratively also to assign negative connotations, for instance when Aunt Voula tries to convince Toula to eat something more as she considers her too skinny (and therefore far from the typical Greek stereotype of curvy women) and compares her to a chicken full of bones (see example 50).

Example 50. My Big Fat Greek Wedding (00:52:31)

\begin{tabular}{|l|l|l|}
\hline VOULA & Here, eat some rice. & Tieni, mangia un po' di riso. \\
\hline TOULA & I don't want any rice, I'm good. & No, non lo voglio, sto bene zia. \\
\hline VOULA & $\begin{array}{l}\text { No, "I'm good." I could snap you like } \\
\text { a chicken! }\end{array}$ & $\begin{array}{l}\text { Sai cosa potrei farti? Disossarti } \\
\text { come un pollo! }\end{array}$ \\
\hline
\end{tabular}

Similarly, Toula's father Gus, after meeting the Millers for the first time, connotes them negatively when he associates them to a piece of toast (see example 51).

Example 51. My Big Fat Greek Wedding (01:07:54)

\begin{tabular}{|l|l|l|}
\hline GUS & $\begin{array}{l}\text { This no work, Maria. They different } \\
\text { people. So dry. That family is like a } \\
\text { piece of toast. No honey, no jam, just } \\
\text { dry. [...] I try to put little marmalade.... } \\
\begin{array}{l}\text { Oh, no, they don't like. They like } \\
\text { themselves all dry and cracking. }\end{array}\end{array}$ & $\begin{array}{l}\text { Non funziona, non funziona } \\
\text { così asciutte. Quella famiglia è } \\
\text { come il pane secco, senza miele, } \\
\text { senza marmellata, asciutti. [...] } \\
\text { Ho cercato di mettere un po' di } \\
\text { marmellata ma a loro non piace, } \\
\text { loro si piacciono asciutti, senza } \\
\text { niente. }\end{array}$ \\
\hline
\end{tabular}


The Millers' coldness is here figuratively represented by the dryness of "a piece of toast" with "no honey, no ham", which would instead render it softer and more mouthwatering; at the same time, the "marmalade" Gus tries to put on that "piece of toast" stands for the liveliness and vitality he thinks of as proper to his Greek people, but as completely absent in the American people, whom he sees as "all dry and cracking". In this sense, by likening the Millers to a piece of toast, Toula's father establishes their bland character that is contrasted with his own family's preference for a flavorful life and, implicitly, for tasty and savory food. Notwithstanding this, at the end of the film, as already observed (see section 3.3, example 25), Gus overcomes his prejudices and uses another metaphorical image related to food in declaring that the Portokaloses and the Millers are "all fruit", thus definitely putting the two families on the same level.

\section{Conclusions}

What has primarily emerged from the contrastive analysis of the dialogues in the original version and in the Italian dubbed version of the films under study is that the ethnic characters constantly stir up memories of their background world by mentioning the original names of their traditional food specialties, which serve as key cultural identifiers, capable of constructing multicultural and multilingual dimensions within which opposing traditions are fused together. Furthermore, a recurrent use of figurative language linked to food, to be observed in both the original versions and the Italian dubbed versions, further ascribes identity to the ethnic characters, thus reinforcing the strict connection between belonging to a specific ethnic group and consuming a certain type of food strongly representative of one's own socio-cultural heritage.

As far as issues of multilingualism and audiovisual translation are concerned, the maintenance of the we-code culinary references in the films' Italian dubbed version ( $99 \%$ of total 76 occurrences) makes "the translated text a site where a cultural other is not erased but manifested" (Venuti 1998: 242) and never obscures the films' original linguistic flavor, thus also satisfying the viewers' expectations and curiosity concerning different ethnic and linguistic traditions.

We could therefore conclude by saying that such recurrent naming of food in the ethnic characters' discourse practices reinforces the role multicultural films play in communicating transcultural stereotypes as well as transnational linguistic identities, assigning the multiethnic communities portrayed on the screen as many layers of symbolism and significance as are the layers in a slice of baklava, where different flavors combine and merge to create a unique, distinctive taste. 


\section{References}

ANCHIMBE, Eric A. (ed.) (2014) Structural and Sociolinguistic Perspectives on Indigenisation: On Multilingualism and Language Evolution. London \& New York: Springer.

AuER, Peter \& Li Wei (eds.) (2007) Handbook of Multilingualism and Multilingual Communication. Berlin: Mouton de Gruyter.

AuER, Peter \& Li Wei (eds.) (2005) "A postscript: code-switching and social identity." Journal of Pragmatics 37, pp. 403-410.

BHATIA, Tej K. \& William C. Ritchie (eds.) (2012) The Handbook of Bilingualism and Multilingualism. Oxford: Blackwell.

BLEICHENBACHER, Lukas. (2008) Multilingualism in the Movies: Hollywood Characters and their Language Choices. Tübingen: Francke.

Bower, Anne L. (2004) Reel Food. Essays on Food and Film. London \& New York: Routledge.

BuCHOLTZ, Mary \& Kira HALl. (2005) "Identity and interaction: a socio-cultural linguistic approach." Discourse Studies VII:4-5, pp. 586-614.

CARTER, Ronald. (2004) Language and Creativity: the Art of Common Talk. London $\&$ New York: Routledge.

Chaume, Frederic. (2004) "Film Studies and Translation Studies: two disciplines at stake in Audiovisual Translation." Meta 49:1, pp. 12-24.

CHIARO, Delia. (2009) "Issues in audiovisual translation." In: Munday, Jeremy (ed.) 2009. The Routledge Companion to Translation Studies. London \& New York: Routledge, pp. 141-165.

DíAz CinTAS, Jorge \& Aline Remael (eds.) (2007) Audiovisual Translation: Subtitling. Manchester: St Jerome.

DRIES, Josephine. (1995) Dubbing and Subtitling. Guidelines for Production and Distribution. Düsseldorf: European Institute for the Media.

EDWARDS, John. (2012) Multilingualism: Understanding Linguistic Diversity. London: Continuum.

GotTlieb, Henrik. (2009) "Subtitling against the current: Danish concepts, English Minds.” In: Díaz Cintas, Jorge (ed.) 2009. New Trends in Audiovisual Translation. Clevedon \& Philadelphia: Multilingual Matters, pp. 21-43.

Gumperz, John. (1982) Discourse Strategies. Cambridge: Cambridge University Press.

IVIR, Vladimir. (1987) "Procedures and strategies for the translation of culture." Indian Journal of Applied Linguistic 13:2, pp. 35-46.

Kelly-Holmes, Helen \& Tommaso M. Milani (eds.) (2013) Thematising Multilingualism in the Media. Amsterdam \& Philadelphia: John Benjamins. 
Leppihalme, Ritva. (2011) “Realia.” In: Gambier, Yves \& Carol Myers-Scotton (eds.) 2011. Handbook of Translations Studies. Amsterdam \& Philadelphia: John Benjamins.

Myers-SCotTOn, Carol. (1993) Social Motivations for Code-switching. Oxford: Clarendon.

Newmark, Peter. (1988) A Textbook of Translation. New York: Phoenix ELT.

PAVESI, Maria. (2009) "Dubbing English into Italian: A closer look at the translation of spoken language." In: Díaz-Cintas, Jorge (ed.) 2009. New Trends in Audiovisual Translation. Clevedon \& Philadelphia: Multilingual Matters, pp. 201-213.

Pedersen, Jan. (2005) "How is culture rendered in subtitles?" In: MuTra 2005 Challenges of Multidimensional Translation: Conference Proceedings. Electronic version: <www.euroconferences.info/proceedings/2005_Proceedings/2005_ Pedersen_Jan.pdf>

RANZATO, Irene. (2016) Translating Culture Specific References on Television: The Case of Dubbing. London \& New York: Routledge.

Siemund, Peter; Ingrid Gogolin; Monika Edith Schulz \& Julia Davydova (eds.) (2013) Multilingualism and Language Diversity in Urban Areas: Acquisition, Identities, Space, Education. Amsterdam \& Philadelphia: John Benjamins.

Snell-Hornby, Mary. (1995) Translation Studies: An Integrated Approach. Amsterdam \& Philadelphia: John Benjamins.

ULRYCH, Margherita. (2000) "Locating Universal Features of Translation Behaviour through Multimedia Translation Studies.” In: Bollettieri Bosinelli, Rosa Maria et al. (eds.) 2000. La traduzione multimediale: quale traduzione per quale testo? Bologna: CLUEB, pp. 407-429.

VENUTI, Lawrence. (1998) The Scandals of Translation: Towards an Ethics of Difference. London \& New York: Routledge.

VInAY, Jean-Paul \& Jean Darbelnet. (1958) Stylistique comparée du français et de l'anglais. Paris: Didier.

VINAY, Jean-Paul \& Jean DARBELNET. (2002) "A methodology for translation." In: Venuti, Lawrence (ed.) 2002. The Translation Studies Reader. London \& New York: Routledge, pp. 128-137.

WEI, Li. (2011) "Moment analysis and translanguaging space: discursive construction of identities in multilingual Chinese youth in Britain." Journal of Pragmatics 43, pp. 1222-1235.

\section{Filmography}

Ae Fond Kiss (Ken Loach 2004)

Bend it Like Beckham (Gurinder Chadha 2002)

Eat Pray Love (Ryan Murphy 2010) 
My Big Fat Greek Wedding (Joel Zwick 2002)

My Big Fat Greek Wedding 2 (Kirk Jones 2016)

My Life In Ruins (Donald Petrie 2009)

The Hundred-Foot Journey (Lasse Hallström 2014)

The Mistress of Spices (Paul Mayeda Berges 2008)

\section{BIONOTE / BIOGRAFIA}

SILVIA MONTI is a researcher in English language at the University of Pavia. In the linguistic field her research interests relate especially to: the presence and functions of code-switching and code-mixing in multilingual audiovisual productions set in cross-cultural environments and the translation strategies related to code-switching and code-mixing in the films' Italian dubbed versions; the varieties of English and their use in present-day language (with particular attention to morphological, lexical and syntactic phenomena; the sociolinguistic functions of dialect, ethnolect, jargon, slang; the contrastive study of British English, American English, Australian English); the translation strategies of slang in the Italian dubbed versions of contemporary British and American films; the linguistic features of Netspeak.

SiLvia Monti è ricercatrice di Lingua inglese presso l'Università degli studi di Pavia. I suoi interessi di ricerca in ambito linguistico vertono in particolare su: la presenza e le funzioni di code-switching e code-mixing in prodotti audiovisivi multilingui e multiculturali e le strategie traduttive relative a code-switching e code-mixing nelle loro versioni italiane doppiate; le varietà della lingua inglese e il loro uso nella contemporaneità (con particolare attenzione a: fenomeni morfologici, lessicali e sintattici; funzioni sociolinguistiche di dialetti, etnoletti, slang, gerghi; studio contrastivo di inglese britannico, inglese americano e inglese australiano); le principali tecniche utilizzate per la traduzione dello slang nella versione italiana doppiata di film britannici e americani contemporanei; le caratteristiche linguistiche del Netspeak. 